\title{
Improving the quality of feedback given to medical students
}

\author{
This article was published in the following Dove Press journal: \\ Advances in Medical Education and Practice \\ 23 November 2015 \\ Number of times this article has been viewed
}

\section{Ravina Tanna \\ Nikhil Patel \\ Department of Medicine, Imperial College School of Medicine, Imperial College London, London, UK}

\section{Dear editor}

We read with great interest the letter by Ah-Kee and Khan ${ }^{1}$ on the competency of junior doctors in providing effective feedback to medical students. We agree that this is an important skill to have as a junior doctor, especially given the requirement to teach as part of the Foundation Programme. However, more than just a requirement, it is important to be able to provide constructive and useful feedback so that medical students are able to improve their practice to become better clinicians in the future.

As final year medical students, we actively seek out junior doctors to listen to our patients' histories, watch us examine patients, and perform clinical procedures. This is because these doctors have recently graduated and thus are closest to us in terms of experience. As such, we feel most comfortable asking them to appraise us and when we receive helpful feedback in return we are likely to seek them out again or opt to shadow them.

Imperial College London makes an active effort to encourage us to teach our peers and in turn, provide effective feedback. This is especially highlighted in the second clinical year where it is compulsory for us to undertake a "Teaching Skills" module. During this course, we are taught what constitutes effective and non effective feedback. One way of emphasizing this is through mini teaching sessions, where in small groups we each have 5 minutes to teach the rest of our group a new, non medical skill. Each person in the group is expected to provide feedback to each individual who has taught, and we are critiqued on the quality of feedback we have given. It is our opinion that at the start of this session, we encountered many of the same barriers as laid out by Hesketh and Laidlaw. ${ }^{2}$ This included providing feedback that was too generalized, inconsistent, and not thorough enough due to fear of upsetting the person to whom you are providing feedback. However, as the session progressed, we greatly improved, and the comments became increasingly more specific and relevant. These barriers can often interfere with various models of learning such as the Kolb's cycle, ${ }^{3}$ which articulates that a person is able to learn and modify his or her behavior through experiences. By breaking down these barriers, we allow for a more fluid learning cycle.

We believe that all junior doctors would have benefited from a course similar to the one that we have described earlier at some point in medical school. As such, junior doctors could take a more prominent role in end-of-firm assessments for medical students. Currently, feedback is provided formally through an assessment by senior clinicians with whom we have little contact. This can make the process a "tick-box" 
exercise as opposed to a meaningful feedback session on our progress. Medical students would benefit more from feedback from members of the team who have more closely observed their practice and with whom they have spent time on the wards. If this change in culture is accepted, then it is even more pertinent that junior doctors are appropriately trained in providing feedback, especially if they currently feel that they are not equipped to do so. Many medical schools have already made attempts to formalize this process by incorporating it into the curriculum, and it is our hope that this can be rolled out country-wide.

\section{Disclosure}

The authors report no conflicts of interest in this work.

\section{References}

1. Ah-Kee EY, Khan AA. Are junior doctors competent in providing effective feedback to medical students? Adv Med Educ Pract. 2015;6: 497-498.

2. Hesketh EA, Laidlaw JM. Developing the teaching instinct, 1: Feedback. Med Teach. 2002;24(3):245-248.

3. McKimm J. Giving effective feedback. Br J Hosp Med. 2009;70(3): 158-161.

Dove Medical Press encourages responsible, free and frank academic debate. The content of the Advances in Medical Education and Practice 'letters to the editor' section does not necessarily represent the views of Dove Medical Press, its officers, agents, employees, related entities or the Advances in Medical Education and Practice editors. While all reasonable steps have been taken to confirm the content of each letter, Dove Medical Press accepts no liability in respect of the content of any letter, nor is it responsible for the content and accuracy of any letter to the editor.

Advances in Medical Education and Practice

\section{Dovepress}

\section{Publish your work in this journal}

Advances in Medical Education and Practice is an international, peerreviewed, open access journal that aims to present and publish research on Medical Education covering medical, dental, nursing and allied health care professional education. The journal covers undergraduate education, postgraduate training and continuing medical education including emerging trends and innovative models linking education, research, and health care services. The manuscript management system is completely online and includes a very quick and fair peer-review system. Visit http://www.dovepress.com/testimonials.php to read real quotes from published authors.

Submit your manuscript here: http://www.dovepress.com/advances-in-medical-education-and-practice-journal 